\title{
PENERAPAN STORY READING UNTUK MENGEMBANGKAN KEMAMPUAN SOSIAL EMOSIONAL ANAK
}

\author{
A. Aisyah Ajeng Wahyuningtiyas. ${ }^{1)}$, A. Fachrurrazi ${ }^{2)}$, Made Ayu Anggreni ${ }^{3)}$ \\ 1,2,3Program Studi Pendidikan Guru Anak Usia Dini \\ Fakultas Keguruan dan Ilmu Pendidikan \\ Universitas PGRI Adibuana Surabaya \\ Email: ${ }^{1}$ aisyahajeng50@gmail.com, ${ }^{2}$ ahmadfachrurrazi@unipasby.ac.id, ${ }^{3}$ ayudekayu@gmail.com
}

\begin{abstract}
Abstrak
Penelitian ini dilatarbelakangi untuk mengembangkan kemampuan sosial emosional anak di TK Muslimat Assasul Huda. Pendidikan tidak hanya memberi pengetahuan tetapi juga mengasah sosial emosiona anak. Mengembangkan kemampuan sosial emosional adalah salah satu cara untuk menghidupkan kembali pendidikan karakter dan moral di kelas, yaitu dengan cara membaca cerita. Anak-anak akan mengalami pengalaman fiksi dalam alam bawah sadarnya yang berperan dalam membentuk kemampuan sosial emosionalnya serta karakter dan moral pribadinya. Tujuan dari penelitian ini adalah untuk mengetahui kemampuan emosi sosial anak sebelum dan sesudah membaca cerita. Penelitian ini menggunakan jenis desain penelitian desain pra-eksperimen dengan desain one-group pretest-posttest design. Subjek dalam penelitian ini adalah 20 anak. Analisis data yang diterapkan dalam penelitian ini adalah hasil dari teknik uji beda pre-and posttest-test ( $T$ test) pengamatan aktivitas anak untuk mengetahui perkembangan kemampuan emosi sosial anak. Hasil penelitian yang dilakukan analisis data diperoleh nilai t_ (hitung) 14,83 dan t_tabel 1,73 dan 2,54. Maka dapat disimpulkan sebagai berikut: t_(hitung) > t_tabel yaitu 2,54> 1,73 dan 2,67, maka $H_{-} l$ diterima dan $H_{-} \_$ditolak. Ini berarti bahwa membaca cerita mempengaruhi kemampuan sosial emosional siswa Taman kanak-kanak.
\end{abstract}

Kata Kunci: Membaca buku cerita, kemampuan sosial emosional

\begin{abstract}
This research was motivated to develop children's social emotional cabilities in Muslimat Assasul Huda Kindergarten. Education not only provides knowledge but also sharpens children's social emotional. Developing emotional social skills is one way to revive character and moral education in the classroom, namely by reading stories. Children will experience fiction in their subconscious which plays a role in shaping their social emotional cabilities and personal character and morals. The purpose of this research was to determine the social emotional cabilities of children before and after reading the story. This research uses a type of research design pre-experimental design with the design of one-group pretest-posttest design. Subjects in this research were 20 children. The data analysis was applied in this study is the result of different test techniques of pre-and post test-test (T test) observation of the children activity to know the development of social emotional abilities of children. The results of research conducted data analysis obtained value $t_{\text {hitung }} 14,83$ and $t_{\text {tabel }} 1,73$ and 2,54. Then it can be concluded as follows: $t_{\text {hitung }}>t_{\text {tabel }}$ that is 2,54 $>1,73$ and 2,67, then $H_{1}$ accepted dan $H_{0}$ rejected. This means that story reading affects the emotional social capabilities kindergarteen students.
\end{abstract}

Keywords: Story reading, emotional social capability 


\section{PENDAHULUAN}

Musbikin (2010) Pendidikan anak usia dini (PAUD) adalah suatu upaya pembinaan yang ditujukan pada anak sejak lahir sampai dengan usia enam tahun yang dilakukan melalui pemberian rangsangan pendidikan untuk membantu pertumbuhan dan perkembangan jasmani dan rohani agar anak memiliki kesiapan dalam memasuki pendidikan lebih lanjut.

Pada masa perkembangannya anak usia dini juga memiliki beberapa karakter yang unik, seperti yang di tulis oleh Maxim (dalam Asmawati 2014) ada beberapa karakteristik anak usia dini diantaranya adalah; (a) Perkembangan fisik ditandai dengan keaktifan anak untuk melakukan berbagai kegiatan; (b) Perkambangan bahasa ditandai dengan kemampuan anak memahami pembicaraan orang lain dan mampu mengungkapkan pikirannya dalam batasbatas tertentu; (c) Perkembangan kognitif ditunjukan dengan rasa igin tahu anak dengan lingkungan sekitarnya; (d) Bentuk permainan anak masih individu, aktivitas bermain anak dilakukan dengan teman sebayanya secara bersama-sama.

Salah satu karakter yang sangat melekat dalam diri anak usia dini adalah anak akan bertanya apapun yang terlintas dipikirannya. Anak usia dini tidak mudah untuk puas dengan jawaban yang guru atau pendidik berikan. Karena itulah guru atau pendidik harus memiliki beberapa media untuk memuaskan rasa keingintahuan anak. Salah satunya adalah dengan membacakan buku cerita kepada anak.

Samsudin (2008) Prinsip-prinsip pembelajaran di taman kanak-kanak salah satunya adalah bermain sambil belajar dan belajar seraya bermain. Melalui bermain anak akan memperoleh dan memperoses informasi belajar. Zaskia (2016) menyatakan, Bermain tidak hanya dengan menggunakan permainan, membacakan sebuah dongeng (story reading) juga merupakan sebuah permainan. Melalui story reading anak akan berimajinasi dan merasakan layaknya tokoh yang diceritakan.

Pada saat story reading anak akan mendengarkan dengan mengimajinasikan setiap cerita yang dia terima didalam alam bawah sadarnya, disinilah anak akan mengalami pengalaman fiktif pada alam bawah sadarnya yang sangat berperan untuk membentuk kemampuan sosial emosionalnya. Musbikin (2010), bercerita atau mendongeng merupakan proses mengenalkan bentuk-bentuk emosi dan ekspresi kepada anak. Hal ini memperkaya pengalaman emosinya yang akan berpengaruh terhadap pembentukan dan perkembangan kecerdasan emosionalnya.

M.Ramli (dalam Nugraheni 2014) menyatakan bahwa sosial emosional anak usia dini merupakan suatu proses belajar anak bagaimana berinteraksi dengan orang lain sesuai dengan aturan sosial yang ada, dan anak lebih mampu mengendalikan perasaanperasaannya sesuai dengan kemampuan mengidentifikasi dan mengungkapkan perasaan tersebut. Proses belajar yang dialami oleh anak terjadi saat guru membacakan sebuah cerita untuk anak. Anak berinteraksi secara langsung dengan guru dan mampu mengendalikan perasaannya saat pembacaan cerita berlangsung.

Guru atau pendidik mampu melakukan interaksi secara intim melalui mendongeng (story reading). Didalam membacakan cerita guru atau pendidik juga mampu menyisipkan pesan-pesan untuk menstimulasi perkembangan sosial emosional anak. Taufik (dalam Musbikin 2010) Cerita-cerita yang dibacakan oleh orang tua maupun guru kepada anak akan memberikan rangsangan pada salah satu bagian otak yang terletak di 
daerah pelipis (lobus temporal), yaitu god spot (bagian otak yang konon "bertanggung jawab' terhadap respons dan mistis manusia), dengan terasahnya god spot ini berarti kecerdasan spiritual anak akan semakin meningkat. God spot mampu berfungsi secara sempurna untuk memberikan bisikan-bisikan suara hati yang senantiasa mendorong kearah tindakan mulia.

Widyastuti (2016), dongeng (story reading) menjadi landasan utama di dalam membentuk karakter atau moral anak. Guru atau orang tua dapat mengajarkan anak tentang moralitas dan mulai membangun sikap, hal ini dapat dimulai dengan menekankan hal-hal sederhana yang tercermin dalam cerita yang dibacakan termasuk perilaku baik dan buruk maupun efek jika anak melakukan perilaku tersebut dalam kehidupan sehari-hari.

Story reading sekarang ini mulai jarang untuk di terapkan di sekolah sebagai salah satu pengisi di waktu luang. Guru lebih memilih untuk memberikan lembar kerja yang akan di kerjakan oleh anak di bandingkan membuat aktivitas yang mengoptimalkan berbagai aspek perkembangan pada anak. Padahal jika di telaah lebih dalam lagi, ada banyak manfaat yang bisa diambil dari membacakan sebuah cerita untuk anak. Guru atau sekolah perlu menerapkan reading time untuk anak. Reading time sendiri adalah waktu yang di khususkan untuk anak dapat bermain dengan imajinasinya ketika dibacakan cerita dalam hal ini dibantu oleh guru kelas pada saat pembacaan cerita (story reading).

Kondisi ini juga terjadi di TK Muslimat Assasul Huda Desa Randegan, Kecamatan Tanggulangin, Kabupaten Sidoarjo. TK Muslimat Assasul Huda belum terlalu memaksimalkan waktu luang anak untuk bermain dengan imajinasinya. Seperti yang peneliti ketahui, di hari Jumat setiap kelas akan mengikuti ekstra secara bergantian yang dimulai dari Kelompok PG, TK A dan kemudian TK B. Waktu transisi pergantian inilah yang menjadi sorotan peneliti. Hari Jumat adalah hari ekstrakurikuler dimana sedari pagi hingga pulang sekolah anak akan mengikuti ekstrakulikuler yang diadakan di sekolah. Guru memberikan beberapa lembar kerja untuk anak kerjakan disaat menunggu giliran ekstra. Banyak anak yang merasa bosan dengan kondisi kelas yang selalu sama sehingga menimbulkan beberapa kekacauan seperti berebut, tidak mau berbagi, berkelahi dan saling olok bahkan tak jarang ada anak yang menangis.

Idris (2014) aktivitas mendongeng atau membacakan cerita dengan bersemangat sangat merangsang kecerdasan maupun kreativutas anak. Melalui story reading, anak juga dapat diajak berkomunikasi serta mencoba untuk melontarkan suatu gagasan terhadap pemecahan suatu masalah. Widyastuti (2016) kehadiran pendidik PAUD ditengah gemuruh kecerian anak saat bercengkrama merupakan sesuatu yang tidak boleh terlewatkan. Oleh karena itu dongeng perlu dijadikan alat bantu pembelajaran di kelas agar anak didik kian bergairah dan bersemangat.

Beberapa hal yang harus diperhatikan dalam malaksanakan story reading adalah pemilihan buku cerita. Kusmiadi dkk (dalam Krisfida 2013) menjelaskan: Pemilihan dongeng harus berdasarkan kriteria-kriteria tertentu yaitu: 1) harus menarik dan memikat perhatian pendongeng sendiri, apabila dongeng menarik dan memikat perhatian maka pendongeng akan bersungguh-sungguh dan mengemas dongeng dengan mengasikkan. 2) dongeng harus sesuai dengan kepribadian anak, gaya anak, dan bakat anak supaya memiliki daya tarik terhadap perhatian anak dan keterlibatan aktif dalam kegiatan mendongeng. 3) dongeng 
sesuai dengan tingkat usia dan kemampuan mencerna isi dongeng anak usia dini. 4) dongeng cukup pendek dalam rentang jangkaun waktu perhatian anak. Anak tidak dituntut untuk mendengarkan cerita dongeng diluar batas ketahanan untuk mendengarkan.

Melalui uraian diatas pendidik juga diminta untuk mengetahui batasan waktu pembacaan cerita kepada anak, agar nak tetap menyukai alur ceritanya dan tidak bosan mendengar ceritanya. Setiap tahapan usia memiliki tahapan waktu pembacaan cerita. Sesuai dengan acuan batasan waktu pembatasan cerita yang ditulis oleh Cakra (2012) berikut acuan batasan waktu pembacaan cerita dan kelompok usianya; (1) Tingkat A, anak didik usia 4-5 tahun pembacaan dongeng kurang lebih 20 menit (jika bisa kurang dari ini); (2) Tingkat B, 5-6 tahun pembacaan dongeng kurang lebih 20 menit; Usia 7-9 tahun pembacaan dongeng kurang lebih 30 menit.

Anak usia dini adalah anak yang mudah bosan, sehingga pendidik harus melalukan beberapa cara untuk membuat suasana mendongeng (story reading) menjadi lebih hidup dan membuat suasana hati anak menjadi senang. Hal inilah yang memuat pendidik anak usia dini diminta untuk memiliki keterampilan dalam berbicara dan bercerita. Pendidik juga wajib untuk mengetahui beberapa langkah-langkah menerapkan dongeng (story reading) kepada anak.

Langkah-langkah menerapkan bercerita (story reading) menurut Moeslichatoen (dalam Fitroh 2015) antara lain; (1) Mengkomunikasi tujuan dan tema dalam kegiatan bercerita kepada anak; (2) Mengatur tempat duduk anak dan mengatur bahan dan alat yang digunakan sebagai alat bantu bercerita; (3) Pembukaan kegiatan bercerita, guru menggali pengalaman-pengalaman anak dengan cerita atau dongeng yang akan diceritakan; (4) Pengembangan cerita yang dituturkan oleh guru; (5) Menetapkan rancangan cara-cara bertutur yang dapat menggetarkan perasaan anak; (6) Menutup kegiatan bercerita dengan mengajukan pertanyaan-pertanyaan yang berkaitan dengan isi cerita.

Hal inilah yang tidak terjadi di dalam ruang lingkup kelas kelompok B di Taman kanak-kanak Assasul Huda, Guru atau pendidik kurang memahami tentang aturan dan langkah serta cara untuk mimilih cerita. Beberapa buku cerita pernah lebih dari sekali dibacakan untuk anak. Sehingga hal ini membuat anak bosan dan tidak tertarik untuk mendengarkan gurunya bercerita. Sehingga anak tidak mau mengikuti aturan yang sudah dibuat di dalam kelas.

Melihat kenyataan tersebut maka diperlukan waktu untuk anak sekedar rehat dari jam belajar menjadi jam bermain yang bisa disederhanakan dengan membacakan sebuah cerita (story reading) untuk anak. Peneliti sangat tertarik untuk mengkaji lebih lanjut dengan mengadakan penelitian uji beda.

\section{METODE PENELITIAN}

Penelitian ini menerapkan pendekatan penelitian kuantitatif eksperimen, menurut sugiyono (2015) metode eksperimen diartikan sebagai metode penelitian yang digunakan untuk mencari pengaruh perlakuan tertentu terhadap yang lain dalam kondisi yang terkendalikan.

Adapun desain penelitian yang digunakan dalam penelitian ini adalah PreExperimental Design dengan bentuk one group pretest-post test Design. Pretest dan posttest merupakan tes yang sama agar hasilnya dapat diperbandingkan. Pretest menginformasikan kemampuan awal (initial position) para subjek sebelum dilakukan penelitian, atau dengan kata lain adalah 
proactive history mereka. Sedangkan posttest adalah tes yang dilakukan setelah diberi perlakuan. Sehinga nantinya skor yang diperoleh adalah peningkatan/penurunan variabel terikat yakni peningkatan atau penurunan kemampuan sosial emosional anak akibat dilakukannya penelitian.
Tes yang dimaksud disini adalah tes kinerja dengan menerapkan metode pengumpulan data melalui observasi kinerja, sedangkan instrumen pengumpulan datanya adalah lembar observasi kinerja untuk mengamati indaktor kinerja yang sudah diteliti

Tabel 1.

Lembar observasi kegiatan story reading

\begin{tabular}{|c|c|c|c|c|c|c|}
\hline \multirow[t]{3}{*}{ No. } & \multirow[t]{3}{*}{$\begin{array}{l}\text { Aspek Perkembangan } \\
\text { Sosial Emosional }\end{array}$} & \multirow[t]{3}{*}{$\begin{array}{c}\text { Perkembangan yang } \\
\text { diamati }\end{array}$} & \multicolumn{4}{|c|}{$\begin{array}{c}\text { Tingkat capaian } \\
\text { perkembangan Sosial } \\
\text { Emosional }\end{array}$} \\
\hline & & & 1 & 2 & 3 & 4 \\
\hline & & & BB & MB & BSH & BSB \\
\hline 1. & $\begin{array}{l}\text { 2.7 Memiliki perilaku yang } \\
\text { mencerminkan sikap sabar } \\
\text { (mau menunggu giliran, } \\
\text { mendengarkan ketika orang } \\
\text { lain berbicara, untuk melatih } \\
\text { disiplin) }\end{array}$ & $\begin{array}{l}\text { Anak mampu menahan } \\
\text { emosinya ketika akan } \\
\text { dibacakan cerita dan saat } \\
\text { dibacakan cerita. }\end{array}$ & & & & \\
\hline 2. & $\begin{array}{l}\text { 2.9 Memiliki perilaku yang } \\
\text { mencerminkan sikap peduli } \\
\text { dan mau membantu jika } \\
\text { dimintai bantuannya }\end{array}$ & $\begin{array}{l}\text { Anak dengan senang hati } \\
\text { memaafkan teman yang } \\
\text { mengganggunya pada saat } \\
\text { akan dibacakan cerita } \\
\text { maupun sesudah dibacakan } \\
\text { cerita }\end{array}$ & & & & \\
\hline 3. & $\begin{array}{l}2.12 \text { Memiliki perilaku } \\
\text { sikap yang mencerminkan } \\
\text { sikap tanggung jawab }\end{array}$ & $\begin{array}{l}\text { Anak dapat saling berbagi } \\
\text { dalam hal apapun dengan } \\
\text { temannya. }\end{array}$ & & & & \\
\hline 4. & $\begin{array}{l}\text { 3.13 Mengenal emosi diri } \\
\text { dan orang lain } \\
4.13 \text { Menunjukan emosi diri } \\
\text { secara wajar }\end{array}$ & $\begin{array}{l}\text { Anak mau untuk bersikap } \\
\text { peduli kepada temannya }\end{array}$ & & & & \\
\hline 5. & & $\begin{array}{l}\text { Anak dapat memahami } \\
\text { tingkah lakunya dan dapat } \\
\text { membedakan mana yang } \\
\text { baik dan mana yang buruk } \\
\text { serta mau meminta maaf } \\
\text { bila melakukan kesalahan. }\end{array}$ & & & & \\
\hline 6. & & $\begin{array}{l}\text { Anak dapat megikuti aturan } \\
\text { dengan baik saat akan } \\
\text { dibacakan cerita dan setelah } \\
\text { dibacakan cerita. }\end{array}$ & & & & \\
\hline 7. & & $\begin{array}{l}\text { Anak mampu mejalin } \\
\text { interaksi sosial dengan baik }\end{array}$ & & & & \\
\hline
\end{tabular}


dan mampu memahami emosi diri serta orang lain.

\section{TOTAL}

\section{Tabel 2}

Capaian perkembangan anak

\begin{tabular}{ll}
\hline Skor & Capaian Perkembangan Anak \\
\hline 4 & (BSB) Berkembang Sangat Baik : Bila anak sudah dapat menguasai kemampuan \\
& sosial emosional sesuai dengan yang diharapkan oleh guru \\
\hline 3 & (BSH) Berkembang Sesuai Harapan : Bila anak sudah mulai menunjukan \\
& kemampuan sosial seusai dengan yang diharapkan oleh guru \\
\hline 2 & $\begin{array}{l}\text { (MB) Mulai berkembang : Bila anak sudah mulai belajar untuk memiliki } \\
\text { kemampuan sosial emosional sesuai yangdiharpkan oleh guru }\end{array}$ \\
\hline 1 & (BB) Belum Berkembang : Bila anak belum menunjukan kemampuan sosial \\
& emosional yang diharapakan oleh guru \\
\hline
\end{tabular}

Observasi yang digunakan dalam pengumpulan data, yaitu observasi terstruktur, menurut Sugiyono (2015) observasi terstruktur yaitu observasi yang telah dirancang secara sistematis, tentang apa yang diamati, kapan dan dimana tempatnya. Jadi peneliti akan menggunakan observasi terstruktur tentang perkembangan perilaku sosial emosional anak dengan menggunakan lembar observasi kinerja. Lembar observasi berisi sebuah daftar perilaku yang mungkin timbul dan akan diamati. Dalam proses observasi, pengamat hanya akan memberikan tanda checklist pada skor yang didapat melalui pedoman observasi yang dibuat.

\section{HASIL PENELITIAN}

Pengumpulan data dan penyajian yaitu Pre-Test dan Post-Test dipaparkan dalam bentuk tabel yang selanjutnya dilakukan uji hipotesis, kemudian mencari hasil uji beda antara Pre-Test dan Post-Test dan mencari hasil uji signifikansi T-test (T hitung) yang di lakukan anak kelompok B TK Muslimat Assasul Huda dengan jumlah 20 anak. Adapun hasil penelitian di sajikan dalam bentuk Tabel 3.

Tabel 3

Uji Beda Pre tes-Pos test

\begin{tabular}{cccc}
\hline Subyek & Pre-Test & $\begin{array}{c}\text { Post- } \\
\text { Test }\end{array}$ & Gain \\
\hline Nadif & 1,91 & 2,20 & 0,29 \\
\hline Alfi & 2,20 & 2,55 & 0,36 \\
\hline Amel & 2,54 & 2,80 & 0,27 \\
\hline Erina & 2,43 & 2,70 & 0,27 \\
\hline Alya & 2,30 & 2,79 & 0,48 \\
\hline Lubab & 2,21 & 2,66 & 0,45 \\
\hline Adit & 2,11 & 2,64 & 0,54 \\
\hline Faris & 1,77 & 2,46 & 0,70 \\
\hline Hasan & 1,91 & 2,32 & 0,41 \\
\hline Khafa & 2,41 & 2,93 & 0,52 \\
\hline Akmal & 2,40 & 2,89 & 0,49 \\
\hline Al- & 2,25 & 2,70 & 0,44 \\
Farisi & & & \\
\hline Zaki & 1,91 & 2,46 & 0,55 \\
\hline Syifa & 2,43 & 2,95 & 0,52 \\
\hline Mita & 2,18 & 2,79 & 0,61 \\
\hline Nisa & 2,02 & 2,73 & 0,71 \\
\hline Shelen & 2,11 & 2,75 & 0,64 \\
\hline Fira23 & 2,27 & 3,02 & 0,75 \\
\hline Shahira & 2,05 & 2,84 & 0,79 \\
\hline Sitara & 2,07 & 2,73 & 0,66 \\
\hline N = 20 & 43,48 & 53,91 & \\
\hline & & & \\
\hline
\end{tabular}


Group Pretest-Postest Design dengan rumus sebagai berikut: $t=\frac{M d}{\sqrt{\frac{\sum X^{2} d}{N(N-1)}}}$

Sehingga dapat diperoleh $t_{\text {hitung }} 14,83$

\section{PEMBAHASAN}

Berdasarkan hasil penelitian diketahui bahwa ada pengaruh "Story reading terhadap kemampuan sosial emosional anak kelompok B di TK Muslimat Assasul Huda". Perlakuan yang diberikan delapan kali menunjukkan anak mengalami perubahan pada perkembangan dalam kemampuan sosial emosionalnya. Treatment pertama anak masih terlihat tidak mau mematuhi aturan yang dibuat guru. 5 anak tidak mau duduk dengan tenang dan tidak mau duduk di bawah bersama teman-temannya. Kegiatan story reading sendiri pernah dilakukan tetapi tidak terlalu sering. Guru lebih sering bercerita kepada anak dibandingkan membacakan anak sebuah buku (story reading)

Treatment ke dua anak-anak mulai terbiasa dengan aturan yang dibuat guru saat akan dibacakan cerita maupun sesudah dibacakan cerita. Treatment selalu dilakukan setiap satu minggu sekali dan pada treatment terakhir perubahan anak dalam mengikuti aturan saat dibacakan cerita maupun sesudah dibacakan cerita, mau berbagi, tidak bertengkar, mau memafkan dan menjalin hubungan dan interaksi yang baik sesama temannya sudah mengalami peningkatan yang signifikan. Hal ini juga disampaikan langsung oleh guru kelas yang membacakan cerita untuk anak. Peningkatan kemampuan yang terjadi pada anak dalam penelitian ini dikarenakan adanya; (1) Ketertarikan anak pada banyaknya ragam cerita yang dibacakan; (2) Ketertarikan anak dengan gambar dalam buku cerita yang dibacakan; (3) Mengisi waktu luang yang biasanya 
WAHANA

Volume 71, Nomor 1, 1 Juni 2019

digunakan untuk mengisi lembar kerja digantikan dengan membaca cerita; (4) Keterlibatan anak secara langsung dalam pembacaan cerita.

Perbandingan $T_{\text {hitung }} 14,83$ dan $T_{\text {tabel }} 1,73$ pada taraf kepercayaan $95 \%$ membuktikan bahwa ada pengaruh story reading terhadap kemampuan sosial emosional anak kelompok B di TK Muslimat Assasul Huda desa Randegan kecamatan Tanggulangin kabupaten Sidoarjo.

Berikut adalah gambaan grafik dari hasil penelitian pengaruh story reading terhadap kemampuan sosial emosional anak kelompok

B.

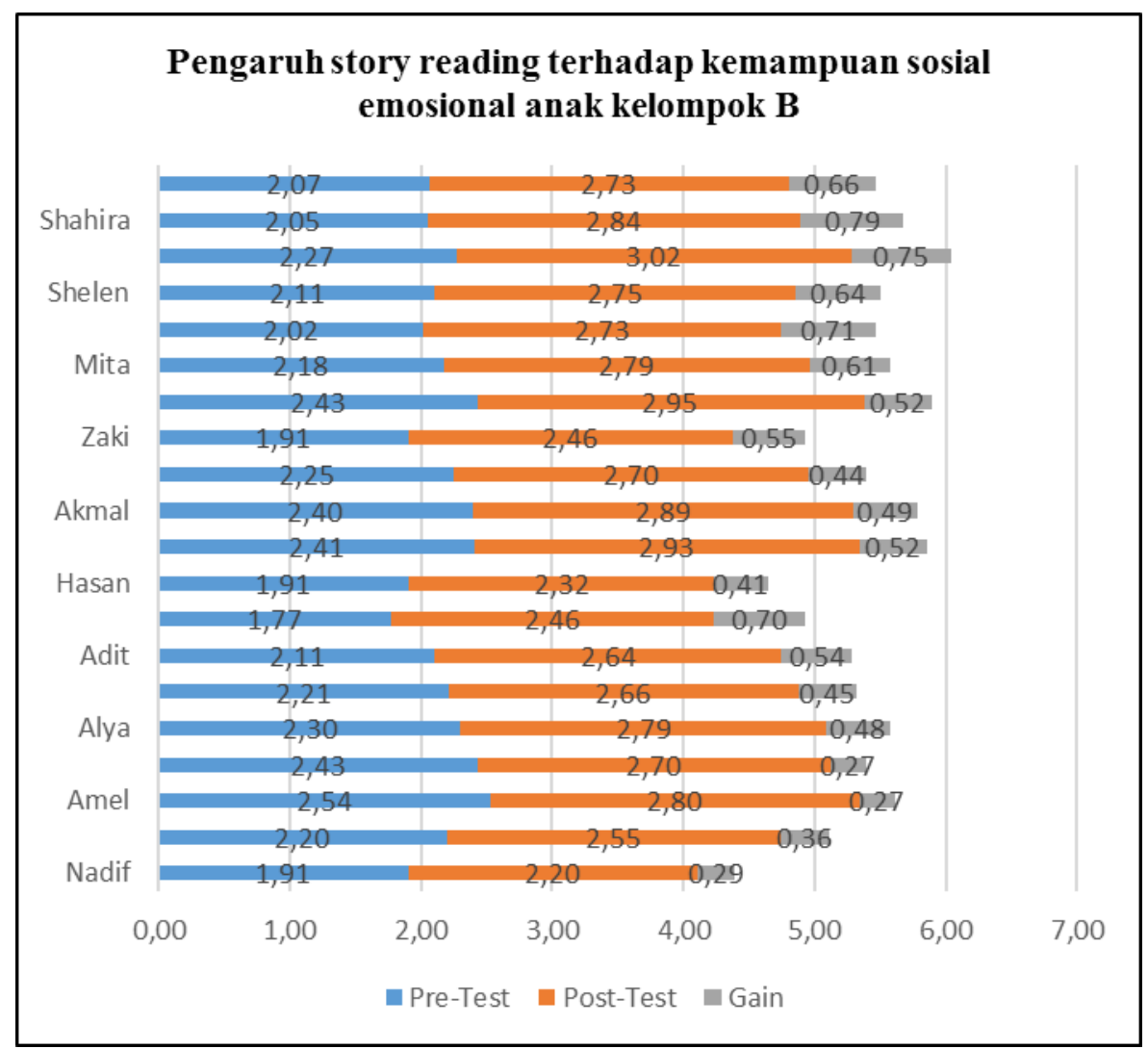


Merujuk pada pendapat Siti Fadjriyani Fitroh (2015), Dongeng (cerita) merupakan rangkaian peristiwa nyata atau tidak nyata yang disampaikan secara sederhana dan mengandung pesan moral yang baik. Kisah nyata itu bisa berupa sejarah, biografi atau testimoni, serta kisah rekaan seperti fabel, mitos, legenda atau hikayat. Sebuah dongeng tak boleh memberi efek samping yang buruk bagi anak, dan ceritanya tidak boleh mengandung unsur takhayul, horor,mkekerasan, pornografi, dan tabu.

Sejajar dengan hasil penelitian yang dilakukan oleh Fitroh, dkk. (2015), yang menyatakan bahwa melalui bercerita juga anak tidak hanya mendapat kesenangan saja, tetapi anak juga mendapatkan pendidikan yang lebih bermakna dan lebih luas, bahkan dapat menyentuh aspek dari pembentukan kepribadian seorang anak ketika dalam masa pertumbuhannya.

\section{KESIMPULAN}

Berdasarkan analisis data yang sudah dilakukan, maka dapat disimpulkan bahwa "Story reading berpengaruh terhdap kemampuan sosial emosional anak kelompok B di TK Muslimat Assasul Huda desa Randegan kecamatan Tanggulangin kabupaten Sidoarjo". Buku cerita yang awalnya sangat jarang mereka sentuh atau baca vahkan di bacakan, kini lebih dekat dengan anak. Melalui cerita anak lebih mudah memahami sesuatu didukung dengan buku cerita bergambar yang dibacakan oleh guru.

Anak-anak dapat memahami pesan yang tersirat didalam buku cerita melalui gambar dan alur disampaikan oleh guru kelasnya. Beberapa nak yang semula tidak mau mengikuti aturan dan tidak bisa tenang, perlahan mulai mengikuti aturan dan mampu untuk duduk tenang mendengarkan. Guru diharapkan agar lebih kreatif dalam membacakan cerita cerita untuk anak, bukan hanya membacakan tetapi juga memilih buku cerita yang sesuai dengan karakter anak didiknya. Guru juga bisa membuat buku ceritanya sendiri sehingga daftar bacaan untuk anak lebih bervariasi. Hasil dari penelitian ini menyatakan bahwa story reading berpengaruh terhdap kemampuan sosial emosional anak maka guru dapat memberikan parenting kepada orang tua agar dirumah anak juga dibacakan cerita sehingga kedekatan antara orang tua dan anak akan terjalin lebih dekat.

Terlebih guru juga dapat membuat buku ceritanya sendiri untuk anak didiknya. Dengan cara tempel dan tulis misalnya, menempel gambar yang sudah kita gunting dari majalah atau print lalu membentuk gambar-gambar acak tersebut menjadi satu rangkaian cerita dengan begitu anak akan lebih tertarik untuk mendengarkan cerita yang akan dibacakan oleh gurunya. Guru juga dapat mengikutsertakan anak untuk membuat buku cerita ini. Hal ini mejadi harapan agar anak akan lebih senang membaca buku dan mendengarkan cerita melalui buku.

Membacakan buku untuk anak sangat luas dan mudah. Tidak hanya buku cerita yang menarik, mungkin guru juga dapat mengenalkan macam-macam buku bacaan kepada anak sehingga anak akan jauh lebih tertarik. Contoh, guru membacakan koran kepada anak tentang pencurian lalu guru memotivasi anak un tuk bersikap jujur.

Ada banyak macam bacaan yang dapat guru bacakan, tidak selalu cerita bergambar dan mahal. Dengan media gambar dan cerita atau buku cerita anak-anak akan sanat mudah mengingat atau memahami sesuatu. 
WAHANA

Volume 71, Nomor 1, 1 Juni 2019

\section{REFERENSI}

Asmawati, Luluk. 2014. Perencanaan Pembelajaran PAUD. Bandung: PT Remaja Rosdakarya.

Cakra, Heru dan Mubarok, Muhfi (Ed). 2012. Mendongeng dengan mata hati. Surabaya: Mumtaz Media.

Fitroh, Fadjryana dan Sari Novita. 2015. "Dongeng sebagai media penanaman karakter pada anak usia dini." Dalam Jurnal PG-PAUD Trunojoyo, Vol 2 (2):76-149.

Idris, H Meity. 2014. Meningkatkan kecerdasan anak usia dini melalui mendongeng. Jakarta Timur: Luxima.

Krisfida, Ribut. 2013. "Pengaruh metode dongeng interaktif untuk meningkatkan mora judment pada anak usia 5-6 tahun”, Online, 1(1): 1-17, http://www.jurnal- online.um.ac.id/article/do/detailarticle/1/40/661, diunduh 28 September 2017 pukul 23.11.

Musbikin, Imam dan Sudjatna, A.S (Ed). 2010. Buku pintar PAUD: Tuntunan lengkap dan praktis para guru PAUD. Jogjakarta: Laksana.

Samsudin. 2008. Pembelajaran motorik di taman kanak-kanak. Jakarta: Litera Prenada Media Group.

Sugiyono. 2015. Metode Penelitian Pendidikan.Bandung: Alfabeta.

Widyastuti, Andini dan Itanov (Ed). 2016. Seabrek kesalahan guru PAUD yang sering diremehkan.

Zaskia, Sasha. 2016. Anak hebat berkat hipnodongeng. Yogyakarta: Laksa 